\title{
REPRODUCTIVE ECOLOGY OF ACANTHUS ILICIFOLIUS L., A NON-VIVIPAROUS MANGROVE ASSOCIATE IN CORINGA MANGROVE FOREST, ANDHRA PRADESH (INDIA)
}

\author{
Jacob Solomon Raju ALURI *, Rajesh BETHAPUDI * and Prasada Rao CHAPPIDI *
}

* Andhra University, Department of Environmental Sciences, Visakhapatnam, India, IN-530003, ajsraju@yahoo.com,raj27prabha@gmail.com, prasadachram@gmail.com

DOI: 10.1515/trser-2017-0018

KEYWORDS: Facultative xenogamy, temporal dioecy, melittophily, explosive fruit dehiscence.

\section{ABSTRACT}

Acanthus ilicifolius L. (Acanthaceae) is an evergreen non-viviparous mangrove associate. It is hermaphroditic, strongly protandrous, self-compatible, facultative xenogamous, temporally dioecious and melittophilous. The floral mechanism is highly specialized and adapted for pollination by large-bodied bees. The natural fruit set is below 30\%. The fruits mature within a month and usually contain four seeds. The fruit is a capsule and splits explosively in the dorsi-ventral plane ejecting the seeds away. This makes it anemochorous. The gregarious occurrence of the plant at the study site is attributed to propagation by seed and vegetative modes.

ZUSAMMENGASSUNG: Die Vermehrungsökologie von Acanthus ilicifolius L., eine nicht-vivipare Mangrove im Gefüge des Coringa-Mangrovenwaldes von Andhra Pradesh (Indien).

Acanthus ilicifolius L. (Acanthaceae) ist ein immergrüne, nicht-vivipare Art im Bestand der Mangrovenwälder Sie ist zweigeschlechtlich, stark protandrisch, selbstkombatible, fakultativ xenogam sowie vorübergehend zweihäusig und melittophil. Der florale Mechanismus ist hoch spezialisiert und für die Bestäubung durch große Bienen angepasst. Die natürliche Fruchtmenge liegt unter 30\%. Die Früchte reifen innerhalb eines Monats und enthalten meist vier Samen. Die Frucht ist eine Kapsel, die explosiv in der dorsi-ventralen Richtung aufreißt, die Samen hinauschleudert und sich daher anemochor d.h. durch den Wind verbreitet. Das gesellige Auftreten der Pflanze am Untersuchungsort wird der Ausbreitung durch Samen und auf vegetative Weise zugeschrieben.

REZUMAT: Ecologia reproductivă la Acanthus ilicifolius L., o mangrovă nonvivipară asociată din pădurea de mangrove Coringa, Andhra Pradesh (India).

Acanthus ilicifolius L. (Acanthaceae) este o mangrovă non-vivipară asociată veșnic verde. Este hermafrodită, cu protandrie accentuată, auto-compatibilă, cu xenogamie facultativă, temporar dioică și melitofilă. Mecanismul floral este foarte specializat și adaptat pentru polenizare de către albinele mari muncitoare. Setul natural de fructe este sub $30 \%$. Fructele se coc în termen de o lună și conțin în majoritatea cazurilor patru semințe. Fructul este o capsulă și se sparge în mod exploziv în plan dorso-ventral expulzând semințele și prin urmare este o plantă anemocoră. Apariția gregară în zona studiată este atribuită propagării semințelor cât și a modului vegetativ de înmulțire. 


\section{INTRODUCTION}

Mangrove biodiversity is important for human well-being through climate regulation, food security and poverty reduction, and also a bio-shield against natural calamities. (Alang et al., 2010; Aziz and Hashim, 2011; Aluri, 2013; Sabai D. and Sisitka H., 2013) Acanthaceae, with some 200 genera and 3,000 species (Souza and Lorenzi, 2005) predominantly have a pan tropical distribution and the American continent harbours the greatest richness and morphological diversity of species (Ezcurra, 1989). Mariette (2000) provided an elaborate account on the function and evolution of stamina filament complex in Acanthaceae with reference to its role in the evolution of pollination syndromes. Acanthus is a genus of about 30 species in the family Acanthaceae. It is native to tropical and warm temperate regions, with the highest species diversity in the Mediterranean Basin and Asia (Barker, 1986; Tomlinson, 1986). Three species A. ilicifolius, A. ebracteatus and A. volubilis are characteristic associates of mangroves and range from India to the Western Pacific (New Caledonia), tropical Australia, and the Philippines (Tomlinson, 1986). Acanthus is poorly known with reference to its reproductive ecology. Fragmentary information on the pollination ecology of A. ilicifolius is available based on brief field studies. Primack and Tomlinson (1980) noted that Acanthus ilicifolius is pollinated by the sunbird, Nectarinia jugularis in Queensland, Australia. Tomlinson (1986) mentioned that A. ilicifolius offers nectar as the main floral reward; it is pollinated by insects, especially bees. Solomon Raju (1990) reported that A. ilicifolius is pollinated by sunbirds, Nectarinia asiatica and N. zeylanica, carpenter bees, Xylocopa latipes and $X$. pubescens, and the wasp, Rhynchium sp. in India. Keeping this state of information in view, the present study was conducted to provide detailed information on the reproductive ecology of Acanthus ilicifolius L. growing in Coringa Mangrove Forest in Andhra Pradesh.

\section{MATERIAL AND METHODS}

Acanthus ilicifolius L. is a landward plant and commonly occurs in oligohaline zone in Coringa Mangrove Forest (16 $30^{\circ}-17^{\circ} 00^{\prime} \mathrm{N}$ and $82^{\circ} 10^{\prime}-80^{\circ} 23^{\prime}$ E) in Andhra Pradesh State, India. But, it also grows occasionally in mesohaline zone where true mangrove plants are removed and kept open. Field investigations and experiments were conducted during the period from February 2013 to October 2016. The inflorescence type and the number of flowers per inflorescence were noted. Ten inflorescences prior to commencement of their flowering were tagged and followed daily to record the flowering duration. Twenty five fresh flowers were used to record the flower type, sex, shape, color, odor, symmetry, calyx, corolla, stamens and style. The floral configuration and rewards presentation aspects were examined in relation to the forage collection activity of insects. Anthesis was initially recorded by observing the marked inflorescences in the field. Later, the observations were made three to four times on different days in order to record accurate anthesis schedule. Similarly, the mature buds were followed to record the time of anther dehiscence. The pollen presentation pattern was also investigated by recording how anthers dehisced and the same was confirmed by observing the anthers under a $10 \mathrm{x}$ hand lens. The presence of nectar was determined by gently pulling a flower from its calyx and firmly pressing its base against a hard surface. The protocols provided by Dafni et al. (2005) were used for measuring the nectar volume, sugar concentration and sugar types. The micropipette was inserted into the flower base to extract nectar for measurement. The average of ten flowers was taken as the total volume of nectar/flower and expressed in $\mu$ l. Similarly, a sample of nectar was used for measuring nectar sugar concentration at selected intervals of time; the Hand Sugar Refractometer (Erma, Japan) was used for this purpose. Nectar was spotted on Whatman no. 1 filter paper along with the standard samples of glucose, fructose and sucrose. The paper was run ascendingly in 
chromatography chamber for 24 hours with a solvent system of n-butanol-acetone-water (4:5:1), sprayed with aniline oxalate spray reagent and dried at $120^{\circ} \mathrm{C}$ in an electric oven for 20 minutes for the development of spots from the nectar and the standard sugars. The developed spots were compared with the spots of the standard sugars to record the sugar types present. Ten mature but un-dehisced anthers were collected from different individuals and placed in a Petri dish. Later, each time a single anther was taken out and placed on a clean microscope slide (75 x $25 \mathrm{~mm})$ and dabbed with a needle in a drop of lactophenol-aniline blue. The anther tissue was then observed under the microscope for pollen. The pollen mass was drawn into a band, and the total number of pollen grains was counted under a compound microscope (40 x objective, $10 \mathrm{x}$ eye piece). This procedure was followed for counting the number of pollen grains in each anther collected. Based on these counts, the mean number of pollen produced per anther was determined. The mean pollen output per anther was multiplied by the number of anthers in the flower for obtaining the mean number of pollen grains per flower. Five dehisced anthers were collected in a Petri dish and the pollen removed from these anthers was examined under microscope for recording the pollen grain features. The pollenovule ratio was determined by dividing the average of the number of pollen grains per flower by the number of ovules per flower. The value thus obtained was taken as pollen-ovule ratio (Cruden, 1977). The stigma receptivity was observed by $\mathrm{H}_{2} \mathrm{O}_{2}$ test. In visual method, the stigma physical state (wet or dry) and the unfolding of its lobes were considered to record the commencement of receptivity; withering of the lobes was taken as loss of receptivity. $\mathrm{H}_{2} \mathrm{O}_{2}$ test as given in Dafni et al. (2005) was followed for noting the stigma receptivity period.

The insect species were observed visually and with binoculars; the species that could not be identified on spot were captured and later identified with the help of the specimens available in Andhra University, Visakhapatnam. Butterflies were identified to species level by consulting the books of Kunte (2007) and Gunathilagaraj et al. (1998). The foraging activities of insects were recorded for 10 minutes per hour for the entire day on three or four occasions and the data was or further analysis, especially to understand the foraging activity rate at different times of the day. Fifty inflorescences were used to record the foraging visits of insects. The data thus obtained was used to calculate the percentage of foraging visits made by each category of insects per day to evaluate their association and pollination role. The insects feeding on nectar and/or pollen were carefully observed to assess their role in effecting pollination. They were observed on a number of occasions for their foraging behavior such as mode of approach, landing, probing behavior, contact with essential organs to result in pollination, and inter-plant foraging activity in terms of cross-pollination. Ten individuals of each insect species were captured while collecting pollen and/or nectar on the flowers; the collection was done during their peak foraging activity period. The captured specimens of insects were brought to the laboratory, washed in ethyl alcohol, stained with aniline-blue on a glass slide and observed under a microscope to count the number of pollen grains present and evaluate their relative pollen carryover efficiency and pollination role.

Mature flower buds of different individual inflorescences were tagged and enclosed in paper bags to test different modes of pollination. The stigmas of flowers were pollinated with the pollen of the same flower manually by using a brush and bagged to test manipulated autogamy. The flowers were fine-mesh bagged as such without hand pollination to test spontaneous autogamy. The emasculated flowers were hand-pollinated with the pollen of a different flower on the same plant and bagged to test geitonogamy. The emasculated flowers were pollinated with the pollen of a different individual and bagged to test xenogamy. All 
these types of pollinations were kept under regular observation until fruit set. Then, the percentage of fruit set and seed set was calculated. The flowers/inflorescences on ten individuals were tagged prior to anthesis and followed for fruit and seed set in openpollinations. The resulting fruit and seed output were pooled up for calculating fruit and seed set rates. During the fruit maturation period, the fruit and seed characteristics were recorded. Regularly field notes record fruit and seed dispersal modes. Casual observations were also made to record whether the seeds germinated immediately after they were dispersed or not.

\section{RESULTS}

Phenology. Acanthus ilicifolius L. inhabits soft muddy soils of brackish water areas but extends to mangrove zonations and becomes dominant after clearing of mangroves (Fig. 1a). The plant is a gregarious bushy shrub due to its ability for vegetative spread to its reclining stems as a result of which it forms large patches by vegetative means. It is erect and grows up to two $m$ tall. The flowering occurs during April-November with peak phase during September-October (Fig. 1b). Inflorescence is terminal or pseudo-axillary bracteate spikes producing $18.21 \pm 6.3$ (Range nine-26) flowers, eight- $20 \mathrm{~cm}$ long, the spike extends with age, peduncle terete and glabrous (Fig. 1c). The flowers are produced acropetally (Fig. 3a). The chronological events of sexual reproduction in this species are detailed in table 1 .

The flower. Flowers are sessile, very large, 35-40 mm long $35 \mathrm{~mm}$ across, bisexual and zygomorphic (Figs. 1d, e and Figs. 2a-i). The calyx is green, sepals four, lobes glabrous, 12-15 mm long and one mm broad, shortly connate in two opposite pairs, the outer pair larger, the upper lobe conspicuous enclosing the flower in bud, the lower lobe somewhat smaller, lateral calyx lobes narrow, wholly enclosed by the upper and lower sepal. The corolla is bluish-violet, $30 \mathrm{~mm}$ long with a short tube closed by basal hairs, upper lip obsolete, lower lip broadly three-lobed and recurved by the middle portion. Four stamens, epipetalous, attached to the throat of corolla tube, didynamous, filaments with thick hairy connectives, 13-16 mm long, stout, curved, more or less flat. The anthers are bilobed (one sterile and one fertile), aggregated around the style, $12 \mathrm{~mm}$ long with thick hairy connectives and medifixed. The pistil is glabrous, ovary superior, two-loculed each with two ovules on axile placenta. The style is 27 $\mathrm{mm}$ long, slender, terete, protruded beyond the stamens while the stigma is semi-wet, bifid.

Table 1: Chronological events of sexual reproduction in Acanthus ilicifolius.

\begin{tabular}{|l|l|}
\hline \multicolumn{1}{|c|}{ Floral event } & \multicolumn{1}{c|}{ Acanthus ilicifolius } \\
\hline Anthesis & $06.00-08.00 \mathrm{~h}$ \\
\hline Anther dehiscence & Mature bud stage \\
\hline Sepals & Persistent \\
\hline Petals & Bi-lipped, bluish-violet \\
\hline Stamens & Four, fall off after two-four days \\
\hline Stigma receptivity & 2nd day of anthesis \\
\hline Nectar volume/flower $(\mu l)$ & $4.12 \pm 0.89$ \\
\hline Nectar sugar concentration (\%) & $41.06 \pm 2.86$ \\
\hline Pollination system & Entomophily \\
\hline Pollinators & Insects, primarily carpenter bees \\
\hline Breeding system & Self-compatible \\
\hline Fruit set in open pollinations (\%) & 28 \\
\hline Fruit maturation time (days) & One month \\
\hline Seed set per fruit & Four \\
\hline
\end{tabular}


Floral biology. The mature buds enlarge and open during 06.00-08.00 h. Since the upper lip is obsolete, the stamens and stigma are exposed without any shelter. The cartilaginous corolla tube has a three-lobed lower lip that acts as landing base for the forager. The staminal filaments hold the sterile and fertile anther locules together with fringed hairs. The development and orientation of stamens are such that the fertile anther lobes are locked in the sterile locule of the facing anther, the pollen receptacle is thus kept firmly closed and can only be separated by the large-bodied probing insect or animal. The open flowers present this state of stamens. Anthers dehisce by longitudinal slits in the mature bud stage (Fig. 3d). The pollen output per anther is 71,837 \pm 186.14 (Range 71,651-72,023) and the per flower average is $2,87,350$. The pollen grains are monosiphonous, dispersed as single grains, aperturate, tri-colporate, yellow, powdery, and $49.8 \mu \mathrm{m}$ in size. Pollen-ovule ratio is 71,837: 1 . The stigma rests on the top of the anthers in bud stage and after anthesis (Fig. 2j; Fig. 3b). It becomes receptive on the morning of the second day of anthesis by growing beyond the height of the stamens, curving down the anthers and slightly diverging its two lobes; the receptivity is lost by the evening of the same day (Figs. 3c, e). The configuration of sex organs and the differential maturation of stamens and stigma were found to prevent self-pollination within the flower but not within the plant and it is further supplemented by strong protandry. The ring of dense hairs present at the base of the stamens where the floral tube narrows, points upward and outward; this arrangement prevents insects from crawling into the floral tube. A flower secretes $4.12 \pm 0.89 \mu \mathrm{l}$ of nectar at the corolla base. The nectar sugar concentration is $41.06 \pm$ $2.86 \%$ and the common sugars include sucrose, glucose and fructose with the first as dominant. The flowers usually last two days while some fall off after three to four days.

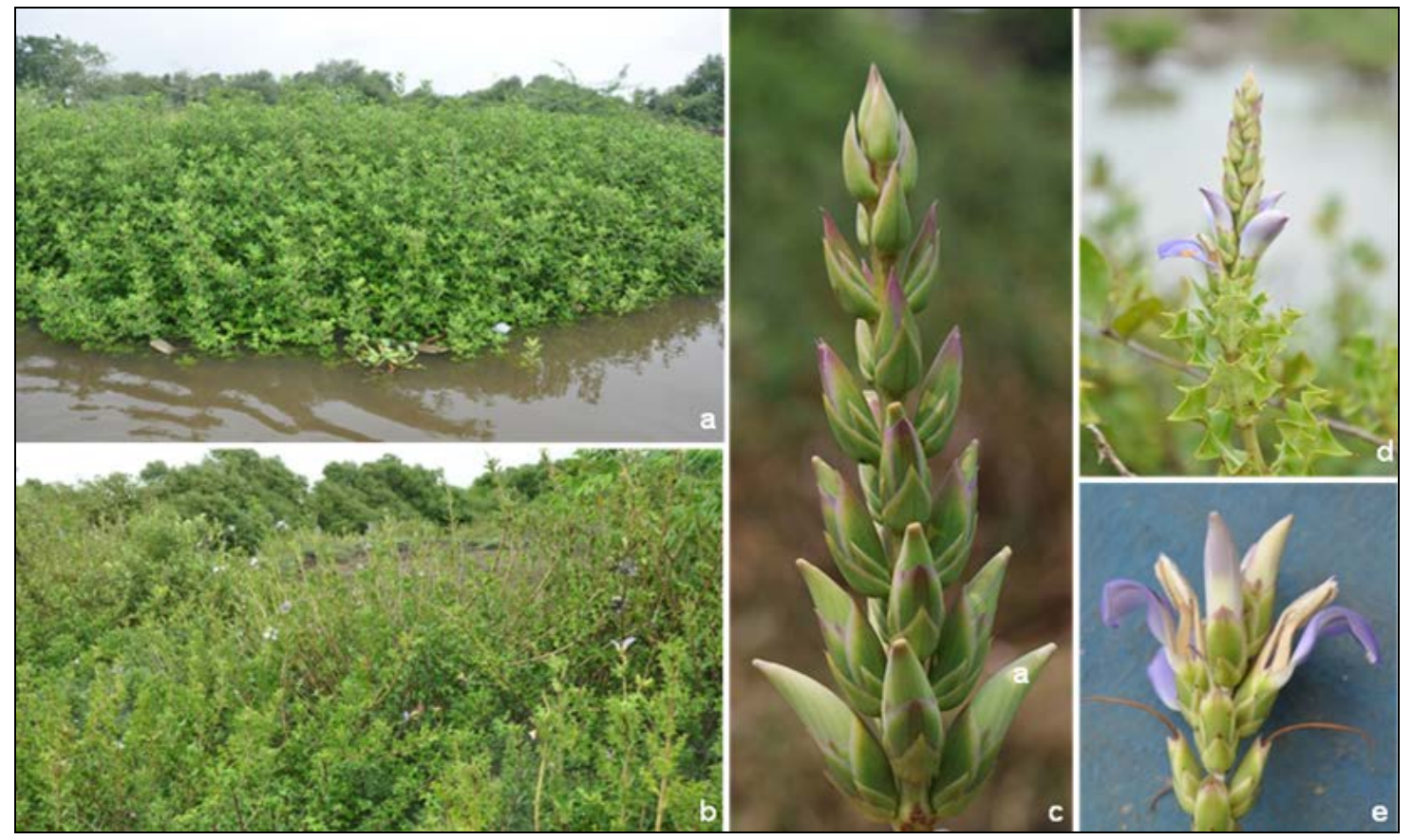

Figure 1: Acanthus ilicifolius: a. habitat - vegetative phase,

b. flowering phase, c. inflorescence, $d$. and e. flowers. 
Breeding systems. Flower bud abortion is absent. The results of breeding systems indicate that the flowers are self-compatible and self-pollinating. Apomixis is absent. The fruit set is absent in spontaneous and manipulated autogamy; but fruit set is $58 \%$ in geitonogamy, $100 \%$ in xenogamy and 28\% in open-pollination (Tab. 2).

Table 2: Results of breeding experiments on Acanthus ilicifolius.

\begin{tabular}{|l|c|c|c|}
\hline \multicolumn{1}{|c|}{$\begin{array}{c}\text { Breeding } \\
\text { system }\end{array}$} & $\begin{array}{c}\text { Number of } \\
\text { flowers } \\
\text { pollinated }\end{array}$ & $\begin{array}{c}\text { Number of } \\
\text { flowers } \\
\text { set fruit }\end{array}$ & $\begin{array}{c}\text { Fruit } \\
\text { set } \\
(\%)\end{array}$ \\
\hline Apomixis & 50 & 0 & 0 \\
\hline Autogamy (bagged) & 50 & 0 & 0 \\
\hline Autogamy (hand-pollinated and bagged) & 50 & 0 & 0 \\
\hline Geitonogamy & 50 & 29 & 58 \\
\hline Xenogamy & 50 & 50 & 100 \\
\hline Open pollinations & 150 & 42 & 28 \\
\hline
\end{tabular}

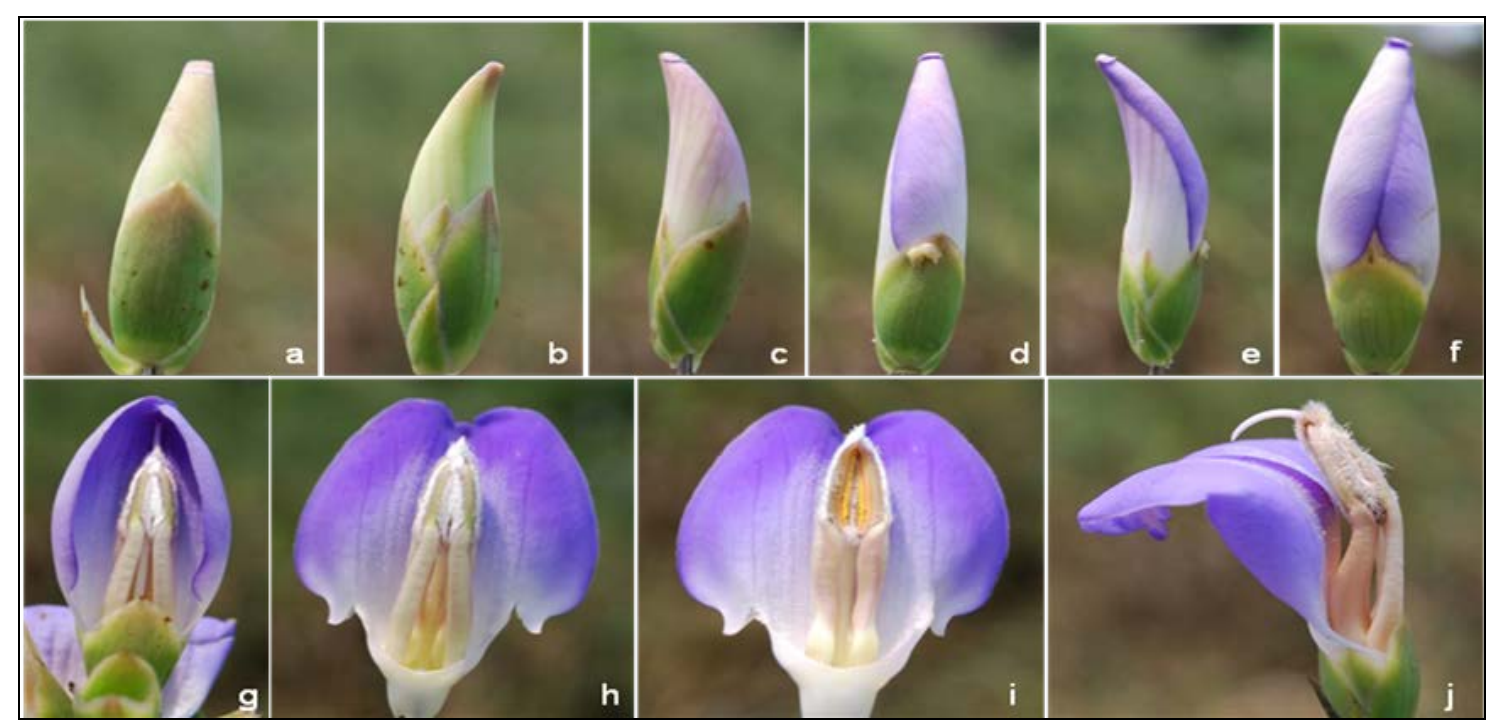

Figure 2: Acanthus ilicifolius: a-i different stages of anthesis, j. unreceptive stigma.
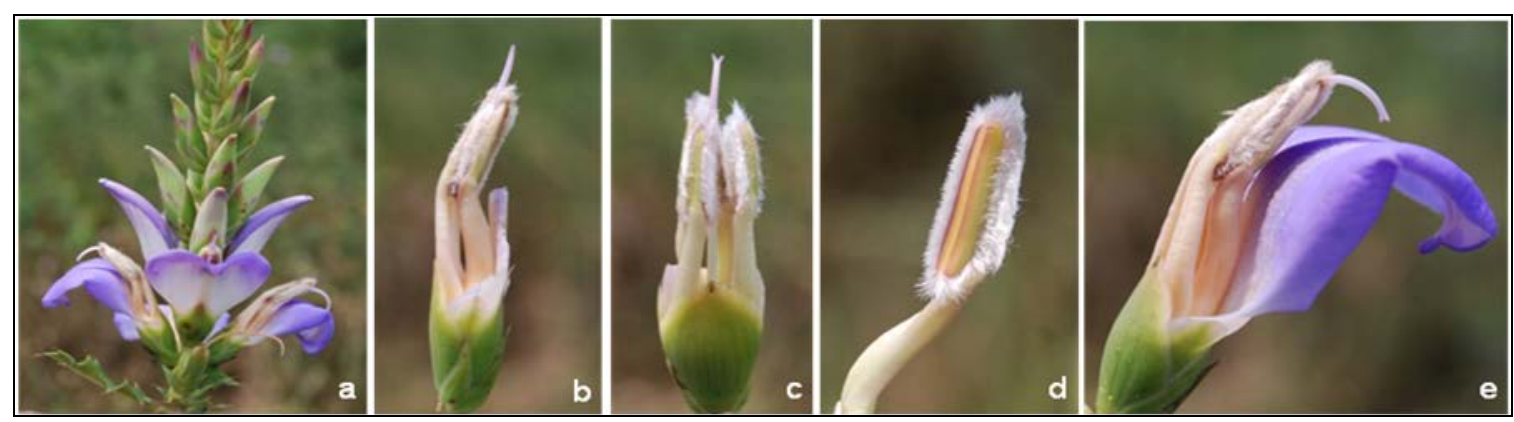

Figure 3: Acanthus ilicifolius: an acropetal anthesis of inflorescences, b. un-receptive stigma, c. receptive stigma by divergent lobes, $d$. anther, e. flower with curved receptive stigma extended beyond the length of anthers. 
Table 3: List of insect foragers on Acanthus ilicifolius.

\begin{tabular}{|c|c|c|c|c|}
\hline Family & Genus & Species & $\begin{array}{c}\text { Common } \\
\text { name }\end{array}$ & $\begin{array}{l}\text { Forage } \\
\text { sought }\end{array}$ \\
\hline \multicolumn{5}{|l|}{ Hymenoptera } \\
\hline \multirow{2}{*}{ Apidae } & Xylocopa & $\begin{array}{l}\text { pubescens } \\
\text { Spinola }\end{array}$ & $\begin{array}{c}\text { Large } \\
\text { Carpenter } \\
\text { Bee }\end{array}$ & Nectar \\
\hline & Xylocopa & $\begin{array}{l}\text { latipes } \\
\text { Drury }\end{array}$ & $\begin{array}{l}\text { Large } \\
\text { Carpenter } \\
\text { Bee }\end{array}$ & Nectar \\
\hline Anthoporidae & Anthophora & $\begin{array}{c}\text { cingulata } \\
\text { F. }\end{array}$ & $\begin{array}{l}\text { Blue } \\
\text { Banded } \\
\text { Bee }\end{array}$ & $\begin{array}{c}\text { Pollen + } \\
\text { Nectar }\end{array}$ \\
\hline Vespidae & Odynerus & sp. & $\begin{array}{c}\text { Black-headed } \\
\text { Mason } \\
\text { Wasp }\end{array}$ & Pollen \\
\hline \multicolumn{5}{|l|}{ Lepidoptera } \\
\hline Hesperiidae & Borbo & $\begin{array}{l}\text { cinnara } \\
\text { Wallace }\end{array}$ & $\begin{array}{l}\text { Rice } \\
\text { Swift }\end{array}$ & Nectar \\
\hline
\end{tabular}
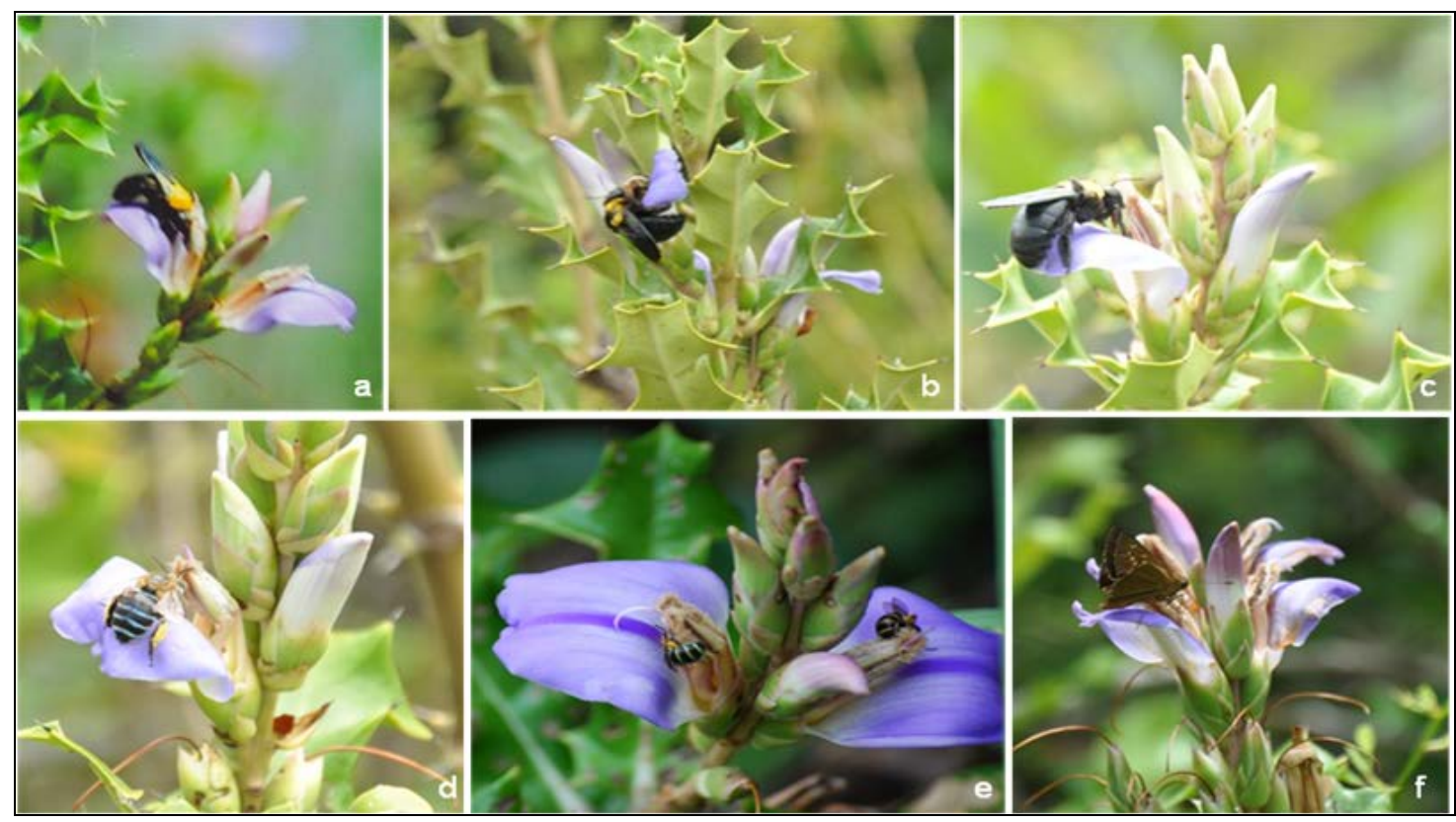

Figure 4: Acanthus ilicifolius: a.-c. different postures of nectar collecting Xylocopa pubescens, d. Anthophora cingulata collecting pollen, e. Odynerus sp. Collecting pollen, f. Hesperiid butterfly, Borbo cinnara collecting nectar. 


\section{Pollination}

The flowers are unspecialized for pollination by large-bodied animals. Fresh flowers are available from morning and remain attractive for two-days for day-active foragers. They were foraged by three bee species, Xylocopa pubescens (Figs. 4a-c), X. latipes and Anthophora cingulate (Fig. 4d), one wasp species, Odynerus sp. (Fig. 4e) and one Hesperiid butterfly, Borbo cinnara (Fig. 4f; Tab. 3). Xylocopa species and Borbo foraged nectar only, Anthophora for both pollen and nectar, Odynerus for pollen only. Both bees and the wasp were the regular and consistent foragers throughout the flowering season while the butterfly was an occasional forager. All these insects except the butterfly foraged from $07^{00}$ to $17^{00} \mathrm{~h}$ with more foraging activity during $10^{00}-12^{00} \mathrm{~h}$ (Fig. 6). The butterfly foraged from $07^{00}$ to $13^{00} \mathrm{~h}$ only (Fig. 6). Xylocopa bees probed the flower channel formed between the stamens and the large corolla lobe below for nectar collection. The bees touched the bases of the stamens due to which they readily diverged in pairs while the style and stigma descended. Following the release of pressure on the stamen bases, the stigma lifted up and the stamens returned back to their original position. In effect, the stigma contacted the back of these bees first and picked up pollen resulting in cross-pollination. The bees captured pollen while departing from the flower and simultaneously the stamens returned back to their original position. The functionality of this floral mechanism rarely led the stigma and the dehisced anthers to contact one another to result in self-pollination. Anthophora bee was medium-sized and its weight was not effective to place pressure on the stamen bases to release anthers from their locked-up position. But, the pollen was placed on the ventral and dorsal side of the bee by the flower when this bee probed for pollen collection. During pollen collection from the frontal portion of the anthers, it contacted the stigma and hence was considered to be important for effecting self- and crosspollination. Odynerus wasp was small-bodied and it also exhibited the same behavior that was exhibited by Anthophora bee during pollen collection and hence was considered to be important in effecting both self- and cross-pollination. Borbo butterfly while collecting nectar had contact with stamens and stigma facilitating the occurrence of self or cross-pollination but its role in pollination was considered to be negligible due to its occasional foraging activity. The bees and wasps were found to visit the same flowers several times in order to gather the forager multiplying the chances for the occurrence of pollination. Such a foraging behavior exhibited by them on the same plant or different plants in the same patch or different patches scattered in the entire width and breadth of the mangrove forest in quest of the forage was found to be promoting the occurrence of cross-pollination. Of the total foraging visits made by the insects, bee visits constituted $83 \%$, wasp visits $9 \%$ and butterfly visits $8 \%$ (Fig. 7). Body washings of these insects revealed the presence of pollen grains; the mean number varied from 244 to 308 for bees, a mean of 235 pollen grains in the wasp and a mean of 66.4 pollen grains in butterflies (Tab. 4). The results indicated that each species is a pollen carrier and the pollen carry-over capacity is related to the body size and probing behavior within or at the flower.

Table 4: Pollen pick up efficiency of foraging insects on Acanthus ilicifolius.

\begin{tabular}{|l|c|c|c|}
\hline Insect species & Sample size & Range & Mean \pm S.D. \\
\hline Xylocopa latipes & 10 & $218-356$ & $308.2 \pm 53.12$ \\
\hline Xylocopa pubescens & 10 & $134-376$ & $238.2 \pm 95.73$ \\
\hline Anthophora cingulata & 10 & $173-367$ & $244 \pm 79.54$ \\
\hline Odynerus sp. & 10 & $173-314$ & $235.8 \pm 59.18$ \\
\hline Borbo cinnara & 10 & $49-89$ & $66.4 \pm 15.12$ \\
\hline
\end{tabular}


Fruiting behaviour. Fruits mature in about a month time. An inflorescence produces $8 \pm 3.2$ (Range four -12 ) fruits. Fruit is a loculicidal compressed capsule, nut-like, ellipsoid or ovoid-oblong, glabrous, $30 \mathrm{~mm}$ long and $10 \mathrm{~mm}$ wide and apiculate. It is initially green and light and dark brown when ripe and dry (Fig. 5a). There are four seeds in each fruit, $10 \mathrm{~mm}$ long, reniform, supported on short-hooked retinacula, testa delicate, wrinkled and whitish (Fig. 5c). The dry fruit capsule splits violently in the dorsiventral plane; the seed stalk is modified into a hook-shaped jaculator that flings out the seeds in an explosive way during fruit dehiscence (Figs. 5b, d). The seeds disperse up to a distance of two m. Such a seed dispersal in its muddy habitats contribute to the formation of monotypic stands and the spread of population if there is no disturbance to these populations from locals. Seeds germinate and produce new plants during the rainy season.
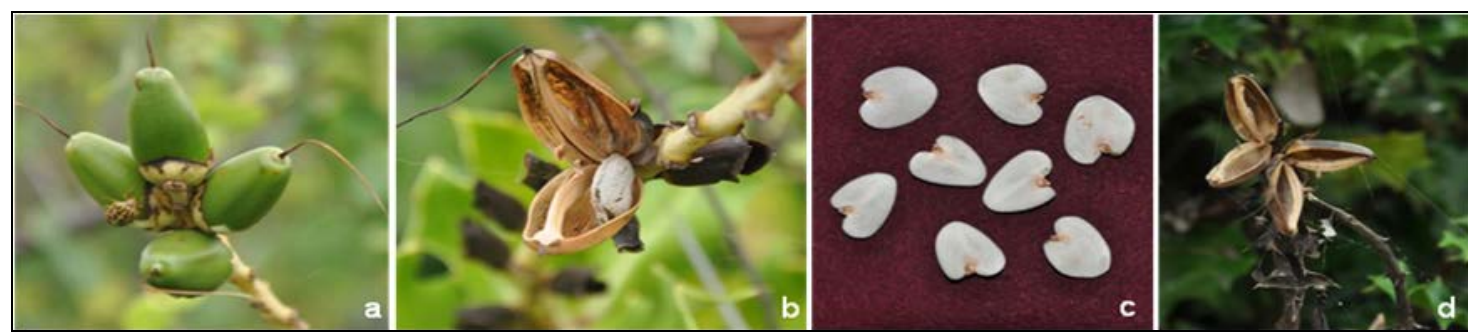

Figure 5: A. ilicifolius: a. maturing fruits, b. dehisced fruit seeds, c. seeds, d. dehisced fruits.

\section{DISCUSSION}

Acanthus ilicifolius L. is a landward gregarious bushy shrub that naturally inhabits muddy soils in the estuarine region. But, it is showing up recently as an invasive nonviviparous species in cleared areas of meso- to poly-haline zones of the study region. It is a very prominent species along the brackish water canals and is involved in assisting the accumulation of soil sediments and stabilization of the floor of the brackish water areas. Different authors have reported the flowering and fruiting seasons differently. Mulik and Bhosale (1989) noted that it flowers during January-May and fruits during April to July. Solomon Raju (1990) reported that it flowers during April-June. Ramasubramanian et al. (2003) noted that it flowers and fruits during May-August in Krishna and Godavari mangrove forests, Andhra Pradesh. Anupama and Sivadasan (2004) recorded that the flowering and fruiting occurs during March-August in the Kerala mangrove forest. Upadhyay and Mishra (2010) recorded that the flowering occurs during January-March in Bhitarkanika and the Andaman and Nicobar Islands. The present study records that A. ilicifolius L. flowers during April-November while fruiting occurs during May-December. These various reports suggest that the flowering and fruiting season in this species is not fixed and the occurrence of these annual recurring events appears to be a function of salinity levels which change annually depending on the rainfall levels as a consequence of climate change.

Tomlinson (1986) noted that Acanthus ilicifolius L. exhibits weak protandry that is likely to restrict self-pollination. In the present study, this species has been found to be strongly protandrous and exhibits temporal dioecy by being staminate on the day of anthesis and pistillate by showing stigma receptivity on the second day. Within the flower, there is no possibility of autogamy or self-pollination in Day one flowers due to un-receptive stigma but geitonogamy is possible due to the simultaneous display of staminate and pistillate phase flowers at plant level. In this context, the hand-pollination tests have been conducted and the results indicated that the plant does not fruit through autogamy but fruits through geitonogamy 
and xenogamy. The results therefore indicate that pollination and subsequent fertilization is essentially a function of pollinators. The plant has mixed breeding system with out-crossing as the principal mode of pollination. This is further substantiated by the high pollen output per flower and pollen-ovule ratio (Cruden, 1977). Primack and Tomlinson (1980) mentioned that A. ilicifolius L. produces fruits from most of the flowers produced. Upadhyay and Mishra (2010) reported that pollination is normally very effective and there is abundance of fruit set in the populations of A. ilicifolius L. studied by them in Bhitarkanika and in Andaman and Nicobar Islands. In the present study, the natural fruit set rate did not exceed 30\% and the fruit set rate is relatable to the intensity of pollinator activity and the state of the nutrient environment of the plant population.

In Acanthus genus, the floral mechanism is very complex and it is evolved with reference to pollination syndrome. Mariette (2000) described four independent floral characters that are involved in the structure of the filament curtain: a fusion of the filaments, decurrent filaments along the corolla wall, a slanting border between the synstapetal and apostapetal corolla regions, and geniculate lower, lateral corolla lobe traces at this border. The evolutionary origin of the filament curtain is considered to be connected with its functions in pollination biology, which are proposed to be those of restricted nectar access, prevention of nectar evaporation, lever arm function facilitating dorsal pollen deposition, and stabilizing of posticous position of anthers and style. Variation in the filament curtain structure appears to be related to different pollination syndromes of the flowers. But, in the total absence of studies on the floral mechanism of individual species of Acanthus, the functioning of such a complex structure of staminal filaments in relation to flower foragers can not be evaluated. Primack and Tomlinson (1980) stated that in A. ilicifolius, the size of the flower and its mechanics require a large pollinator for effective pollination. These authors also mentioned that the sunbird, Nectarinia jugularis is the pollinator in Queensland, Australia. Tomlinson (1986) described that A. ilicifolius flowers offer nectar as the main floral reward and are pollinated by insects, especially bees and birds. Solomon Raju (1990) reported that this plant species is pollinated by sunbirds, Nectarinia asiatica and N. zeylanica, carpenter bees, Xylocopa latipes and $X$. pubescens, and the wasp, Rhynchium sp. in the present study area. After 24 years, the present study was taken up and it is found that A. ilicifolius is pollinated by bees consisting of Xylocopa, Anthophora and the wasp Odynerus sp. at the same site. Of these, Xylocopa is the most appropriate forager to work out the floral mechanism to access nectar and pollinate the flowers effectively and this observation refutes the report by Primack and Tomlinson (1980) that Xylocopa bees do not visit the flowers of A. ilicifolius. During the study period, the sunbirds never visited the flowers and their presence was also not sighted. Similarly, the wasp, Rhynchium sp. has never visited the flowers of A. ilicifolius but it is present in the area and concentrated on the flowers of Lumnitzera racemosa for nectar. The absence of sunbird activity seems to be related to land use changes and conversion of certain pockets of the mangrove forest.

In A. ilicifolius L., the flowers are nectariferous and available during day time. The complex floral mechanism functional in this species appears to have evolved to conceal and protect the nectar from the flower foragers that do not bring about pollination during nectar collection. This floral mechanism is highly specialized and only those foragers that forcefully touch the bases of stamens can access the nectar. When such foragers touch the stamens, the latter readily diverge in pairs and style and stigma descends; following the departure of the foragers, the pressure on the stamen bases is released, the stigma lifts up and the stamens return back to their original position. Then, the stigma sweeps against the dorsal side of the foragers first and in effect picks up the 
pollen (if it is already there on the bee which it carried from the previously visited flowers) and the stamens also deposit the pollen on the bee simultaneously. This is how pollination occurs. The Day one flowers serve as pollen donors only since the stigma is not receptive while the Day two flowers as pollen receivers due to the receptivity of stigma. The effective pollinators of A. ilicifolius L. in this study are Xylocopa and then Anthophora bees. Therefore, the success of sexual reproduction in A. ilicifolius under the current state of mangrove forest almost exclusively depends on Xylocopa bees. These bees are abundant in the forest due to availability of their nesting sites. The wood of Excoecaria agallocha and Brownlowia tersa are used as nesting sites by these bees. Other bees and wasps also nest in mangroves and are therefore more dependent on mangrove plants for their existence (Tomlinson, 1986). The study shows that A. ilicifolius with a highly specialized pollination mechanism is pollinated in principle by carpenter bees of the genus Xylocopa. The plant thrives as long as the carpenter bees are available in the mangrove forest.

Upadhyay and Mishra (2010) stated that Acanthus ilicifolius L. takes thirty four days to complete the phases of floral bud to mature propagules in Bhitarkanika and the Andamans. Tomlinson (1986) noted that this species ejects seeds from the fruits violently. Similarly, Das and Ghose (2003) also mentioned the same. In the present study also, it is found that A. ilicifolius L. takes about a month time to produce mature fruits each containing mostly four seeds. The fruit is a capsule and splits explosively in the dorsiventral plane ejecting the seeds away and hence it is anemochorous. Anemochory is effective only for those fruits that mature and split during dry season. The fruits that mature during rainy season for dispersal do not split violently due to high ambient humidity and rainfall. These fruits remain in place with the mother plant and gradually dehisce releasing seeds passively. Therefore, the expansion of the population of A. ilicifolius is largely dependent on effective anemochory which is functional during dry season, especially in May.

Tomlinson (1986) reported that A. ilicifolius has the ability for vegetative spread due to its reclining stems and as a result it forms large patches by vegetative means. This characteristic is important for the sprawling habit exhibited by this species. Perhaps the gregarious occurrence of the plant can be linked to propagation by both seed and vegetative means. The ability to have both sexual and asexual means of propagation is a "fail-safe mode" with which it is able to survive and build-up its population even in isolated areas and hence expands its distribution range.

\section{CONCLUSIONS}

Acanthus ilicifolius L. (Acanthaceae) with hermaphroditic flowers exhibits protandry, self-compatibility, facultative xenogamy and temporal dioecy. The floral mechanism is highly specialized and adapted for tripping by large bees. Fruits disperse by explosion and are anemochorous. The plant reproduces by seed as well as vegetative mode and hence has the ability to extend and expand its distribution in mangrove habitats. Cleared mangrove forests are soon occupied by this plant and its populations are an invasive species. 


\section{REFERENCES}

1. Alang R. N. N. R., Jusoh W. F. A. W., Nur-Zati A. M. and Hashim N. R., 2010 - Ant diversity on Sonneratia caseolaris trees in Rembau-Linggi mangrove forest, Peninsular Malaysia, Transylvanian Review of Systematical and Ecological Research, 10, The Wetlands Diversity, 77-82.

2. Aluri J. S. R., 2013 - Reproductive ecology of mangrove flora: conservation and management, Transylvanian Review of Systematical and Ecological Research, 15.2, The Wetlands Diversity, 133-184.

3. Anupama C. and Sivadasan M., 2004 - Mangroves of Kerala, India, Rheedea, 14, 9-46.

4. Aziz T. N. A. and Hashim N. R., 2011 - Heavy metal concentrations in an important mangrove palm (Nypa fruticans), in Rembau-Linggi Mangrove Forest (Peninsular Malaysia); Transylvanian Review of Systematical and Ecological Research, 12, The Wetlands Diversity, 111-117.

5. Barker R. M., 1986 - A taxonomic revision of Australian Acanthaceae, Journal of Adelaide Botanic Gardens, 9, 64-75.

6. Cruden R. W., 1977 - Pollen-ovule ratios: a conservative indicator of breeding systems in flowering plants, Evolution, 31, 32-46.

7. Dafni A., Kevan P. G. and Husband B. C., 2005 - Practical Pollination Biology, Enviroquest Ltd., Ontario, 590.

8. Das S. and Ghose M., 2003 - Seed structure and germination of some Indian mangroves - a taxonomic interest, Taiwania, 48, 287-298.

9. Ezcurra C., 1989 - Ruellia sanguinea (Acanthaceae) y especies relacionadas en Argentin, Uruguay y sur de Brasil, Darwiniana, 29, 269-287. (in Spanish)

10. Gunathilagaraj K., Perumal T. N. A., Jayaram K. and Ganesh Kumar M., 1998 - Field Guide: Some South Indian Butterflies, Niligiri Wildlife and Environmental Association, Niligiri, 274.

11. Kunte K., 2007 - A lifescape of butterflies of peninsular India, University Press, Hyderabad, 254.

12. Mariette M., 2000 - The filament curtain: a structure important to systematics and pollination biology in the Acanthaceae, Botanical Journal of Linnean Society, 133, 129-160.

13. Mulik N. G. and Bhosale L. J., 1989 - Flowering phenology of the mangroves from the west coast of Maharashtra, Journal of Bombay Natural History Society, 86, 355-359.

14. Primack R. B. and Tomlinson P. B., 1980 - Variation in tropical forest breeding systems, Biotropica, 12, 229-231.

15. Ramasubramanian R., Ravishankar T. and Sridhar D., 2003 - Mangroves of Andhra Pradesh. Identification and Conservation Manual, M. S. Swaminathan Research Foundation, 65.

16. Sabai D. and Sisitka H., 2013 - Analysing learning at the interface of scientific and traditional ecological knowledge in a mangrove ecosystem restoration scenario in the eastern coast of Tanzania, Transylvanian Review of Systematical and Ecological Research, 15.2, The Wetlands Diversity, 185-210.

17. Solomon Raju A. J., 1990 - Observations on the floral biology of certain mangroves, Proceedings of Indian National Science Academy, B56, 367-374.

18. Souza V. C. and Lorenzi H., 2005 - Botanica sistematica: Guia ilustrado para identificacao das familias de Angiospermas da flora brasileira, baseado em APG II, Plantarum, Nova Odessa, 640. (in Portuguese)

19. Tomlinson P. B., 1986 - The Botany of Mangroves, Cambridge University Press, Cambridge, 441.

20. Upadhyay V. P. and Mishra P. K., 2010 - Phenology of mangrove tree species on Orissa coast, India, Tropical Ecology, 51, 289-295. 